\title{
Continuous Firing
}

National Cancer Institute

\section{Source}

National Cancer Institute. Continuous Firing. NCI Thesaurus. Code C63265.

Problem associated with the excessive production of electrical impulses over a period. 